\title{
Habilidades de discriminação auditiva em crianças com desvios fonológicos evolutivos $* * * *$
}

\author{
Hearing discrimination abilities in children with phonological \\ disorders
}

\author{
Beatriz dos Santos-Carvalho* \\ Helena Bolli Mota** \\ Márcia Keske-Soares** \\ Tiago Mendonça Attoni***
}

*Fonoaudióloga. Mestre em Distúrbios da Comunicação Humana pela Universidade Federal de Santa Maria (UFSM). Endereço para

correspondência: R. das Petúnias, 227 Santa Rosa - RS - CEP 98900-000 (fgabeatriz@yahoo.com.br).

**Fonoaudióloga. Doutora em Linguística Aplicada pela Pontifícia Universidade Católica do Rio Grande do Sul. Professora do Curso de Mestrado em Distúrbios da Comunicação Humana da UFSM.

***Fonoaudiólogo. Mestre em Distúrbios da Comunicação Humana pela UFSM.

****Trabalho Realizado na UFSM.

Artigo Original de Pesquisa

Artigo Submetido a Avaliação por Pares

Conflito de Interesse: não

Recebido em 05.05.2009.

Revisado em 21.11.2009; 17.12.2009;

22.12.2009.

Aceito para Publicação em 01.09.2010.

\section{Abstract}

Background: hearing discrimination abilities in children with phonological disorders. Aim: to investigate the ability of hearing discrimination in children with Phonological Disorders who received or were receiving phonological treatment; to verify if the altered phonemes were the same as those which were not discriminated in the Picture Test for Hearing Discrimination (adapted for Portuguese language by Mota et al 2000, based on "The Boston University Speech Sound Discrimination Picture Test") and to verify if the ability of hearing discrimination is related to gender, age and the phonological disorder severity level. Method: 41 children, 16 females and 25 males, with ages ranging between 4 and 8.2 years were evaluated. Data used for analyses were taken from the results obtained in the Picture Test for Hearing Discrimination and from the Phonological Assessment. Results: no statistically significant difference between genders Statistical analyses also indicated that the performance in the Picture Test for Hearing Discrimination was correlated to age. The more severe the phonological disorder the higher the number of phonemes that were not discriminated. Conclusions: hearing discrimination inability can be a causative or aggravating factor of phonological disorder, although this rule does not apply to all cases. Key Words: Noise; Hearing Discrimination Abilities; Speech Perception; Evolutive Phonological Deviation.

\section{Resumo}

Tema: a habilidade de discriminação auditiva em crianças com desvio fonológico evolutivo. Objetivo: investigar esta habilidade nestas crianças, que recebiam ou haviam recebido tratamento fonoaudiológico; verificar se os fonemas alterados no sistema fonológico eram os mesmos não discriminados no teste de figuras para discriminação auditiva (adaptado por Mota et al. 2000, do "The Boston University Speech Sound Discrimination Picture Test") e se as habilidades de discriminação auditiva relacionavam-se com o sexo, a idade e o grau de severidade do desvio fonológico evolutivo. Método: os dados utilizados foram referentes a 41 crianças, sendo 16 do sexo feminino e 25 do sexo masculino, com idades compreendidas entre 4 anos e 8 anos e 2 meses, e foram coletados por meio da avaliação fonológica da criança e do teste de figuras para discriminação auditiva. Resultados: observou-se que não houve diferença estatisticamente significante de desempenho no teste de figuras para discriminação auditiva entre os sexos e que o melhor desempenho no teste está correlacionado estatisticamente com o avanço da idade cronológica. Quanto mais severo for o desvio fonológico evolutivo maior é o número de fonemas para os quais a criança apresenta inabilidade de discriminação auditiva. Conclusão: a inabilidade de discriminação auditiva pode ser um fator causal ou agravante do desvio fonológico evolutivo, embora não se aplique a todos os casos. Palavras-Chave: Percepção da Fala; Discriminação da Fala; Deficiências Fonológicas. 


\section{Introduction}

To realize a sound, the human being needs have integrity of organic structures involved the detection process, reception, conduction and interpretation and should be exposed to incentive sonorous (1-3). Researches $(4,5)$ point to the fact that the baby more pay attention to the speech sounds than the other surrounding sounds.

The learning of speech sounds only occurs when conditions to have been have discriminat each other, which provides units acceptables to the verbal expression of thought. The auditory discrimination improves with increasing of age and is influenced by the interplay of maturation and experience (6).

The phonological disorders (PD) represent deviations in the implementation of the contrastive acquired phonemes, involving the system disorder, in, other words, that precludes meanings through the structure of tongue sounds (7).

Researches has been conducted with the aim of find what causes the PD. Some point to inability to discriminate auditory sounds as being a cause factor of this deviation (8-10).

In the Brazilian literature, have few studies available for the auditory discrimination and their relationship with the PD. This work had to aim verify the relationship between phonemes changed in the phonological system of children with PD and those for who test she has disability auditory discrimination. Also relate performance in the figures test for auditory discrimination FTAD (11) with gender, age and grade of severity of the PD.

\section{Method}

This research was accomplished by research in database, the project recorded in the Committee Ethics in Research of the Center for Health Sciences (CHS), under number 066/04, with subjects attended the service speech therapy (SST) of the Federal University of Santa Maria (UFSM). All subjects signed the therm of free and informed consent, to undergo assessment and treatment in this institution, and authorizing the publication of results obtained.

The sample was 41 subjects with PD and 16 females and 25 males, with ayes between 4 years and 8 years and 2 months.

The datas for FTAD (11) results of the assessment of phonological child (AFC) (12) and the degree of severity of phonological disorders (13).

PD was considered by, children whose main change being located in the system disorder, with out significant changes of speech organs, with hearing thresholds within the normal range without changes neurological or otorhinolaryngology that interfere in the mechanism of speech production, with normal intellectual abilities over the age 4 years (14).

For the assessment of auditory discrimination was applied the FTAD, a adaptation (11) to "The Boston University Speech Sound Discrimination Picture Test". The FTAD protocol is in the Appendix of this article.

In this test, are presented 25 pairs of words that differ in only one phoneme (pairs minimal), represented in the form of figures. For each pair are presented at least three cards containing two drawings each. For example the minimum pair "boat" versus "goat" in three cards: one with two designs goats, another with two drawings of boats and a third with a drawing of a goat and a boat.

The child tested must hear the pronunciation of two words of the pair, which may be the same or different and point to the card containing the figures corresponding to the words heard. If the childe no properly answer to a pair of pictures after the submission of other couples, that is retested (second column of the Protocol, Appendix).

At the end of test is calculated the percentage of correct child, which is considered god if it exceeds $80 \%$ (15). Thus, we evaluate the ability of the child auditive discriminate the speech's.

To phonemes assess phonological used the AFC the child (12). The datas collected through this instrument were analyzed using analysis contrastive.

In order to determine the severity of the PD was calculated the correct consonants percentage (PCC) (13). Deviation's levels, according to the results PCC, are classified as average (86 to 100\%), average-moderate (66 to 85\%); deviation moderate-severe (51 to $65 \%$ ), severe disorder $(<50 \%)$.

All data were analyzed

statistically. It the datas distributed normally. And used nonparametric analysis. For categorical variables was used the Spearman test to verify mean difference was used to test $U$ of Mann - Whitney and for analysis of independent samples the Kruskal-Wallis. Data were considered statistically significant if $\mathrm{p}>0,05$.

\section{Results}

We analyzed the average performance of two sexes of FTAD: women (16 subjects), $83.37 \%$ of items ( $\mathrm{SD}=0.132961$ ), male (25 subjects), $78.98 \%$ of correct answers ( $S D=0.15238)$. Applying the nonparametric Kruskal Wallis, obtained $\mathrm{p}=0.3354$ (not significant).

In Table 1, to assess the relationship between the auditory discrimination with age, calculated Spearman coefficient correlating these two variables. Obtained $\mathrm{r}$ $=0.345672$ and $p=0.026852$. These data show that there is a weak positive correlation, but significant, 
between performance in FTAD and age of the subjects.

Next, compared the severity of PD, and performance in FTAD. For this, the Subjects were divided in groups according to the PCC (13) and then was made averaging Correct answers FTAD for each group. In the sample, only one subject had severe the $\mathrm{PD}$, with an average success rate of $70.58 \%$ in FTAD.

Five subjects had PD moderately severe, with an average of 76.42\% of items in FTDH (SD 0.202949). Twenty-three subjects had moderate deviation, mean $81,22 \%$ of correct FTDH (SD = 0.146055). Twelve subjects had an average deviation, averaging hit rate of $82.30 \%$ in FTAD (SD 0.114025).

To see if there was a significant difference between groups, applied the nonparametric for independent samples Kruskal Wallis, obtaining $\mathrm{p}=0.8497$, with what follows that no statistically significant difference between performance in FTAD and the varying severity of the PD.

After collecting the data, it was considered relevant for this research to classify the individuals in relation to the percentage of correct FTAD. Through this classification, it was possible to situate sample as having good or bad performance this test.

Two subjects ( $4.87 \%$ of the sample) were at in the range of correct 40 to $49 \%$. One subject (2.43\%) remained in the range of 50 to $59 \%$ of correct FTAD.
Six subjects (14.63\%) were between 60 and 69\%; nine (21.95\%) between 70 to $79 \%$ of hits and ten (24.9\%) between 80 and $89 \%$. Eleven subjects (26.82\%) were between 90 and $99 \%$ of correct FTAD and, finally, two subjects (4.87\%) agreed $100 \%$.

Table 2 shows one of the objectives of research: check for equality phonemes changed in the phonological system and FTAD. For this, called errors in common where was this relationship. Errors in common were compared to the severity of the PD and the percentage of correct FTAD.

To analyze the relationship between the variables in Table 2, tested for a correlation between them. Applying the nonparametric Spearman found a negative correlation between average the value of the PCC (the severity of PD) and errors in common, with value of $r=-0.51614$, the higher the PCC (the lower the severity of the PD) lower the number of common errors in the system phonological and auditory discrimination. This Correlation is significant because the value of $p=0.000552$.

Table 3 shows the results comparing the common errors in the percentage of correct FTAD. By means of the Spearman test, it was found that there is a strong negative correlation between the percentage of correct FTAD and errors in common value of $r=-0.72881$. This correlation is very significant, as $\mathrm{p}=0.0000000656$.

TABLE 1. Performance FT AD in relation to age.

\begin{tabular}{|c|c|c|c|c|c|}
\hline Variables Correlated & $\mathrm{N}^{\mathrm{o}}$ subject & mean & StandardDeviation & $r^{*}$ & p-amount \\
\hline FTAD & & $80,69 \%$ & 0,145032 & & \\
\hline Age & 41 & 75 months & 13,01879504 & 0,345672 & 0,026852 \\
\hline
\end{tabular}

Legend: FTDH-performance test figures for Auditory Discrimination.

TABLE 2. Common Errors in the Phonological System and Auditory Discrimination in Relation to the severity of the PD

\begin{tabular}{cccccc}
\hline $\begin{array}{c}\text { Grade of Sev. } \\
\text { PD }\end{array}$ & $\begin{array}{c}\mathrm{N}^{\mathrm{o}} \\
\text { subject }\end{array}$ & $\begin{array}{c}\text { Mean number } \\
\text { of errors PS }\end{array}$ & $\begin{array}{c}\text { s.d. common } \\
\text { PS }\end{array}$ & $\begin{array}{c}\text { Mean errors in } \\
\text { common PS and } \\
\text { FTDH }\end{array}$ & $\begin{array}{c}\text { s.d. common } \\
\text { errors }\end{array}$ \\
\hline $\begin{array}{c}\text { severe } \\
\begin{array}{c}\text { moderate- } \\
\text { severe }\end{array}\end{array}$ & 1 & 12 & - & 6 & - \\
$\begin{array}{c}\text { average- } \\
\text { moderate }\end{array}$ & 23 & 13 & 3,08220700 & 6,4 & 4,27785 \\
average & 12 & 7,13 & 2,37992260 & 2,56 & 0,000552 \\
\hline
\end{tabular}

*Spearman correlation

Legend: Sev. - Severity; PD - phonological disorder; PS-phonological System ; dp - Standard deviation; FTAD - Figures

Test for auditory Discrimin ation. 
TABLE 3. Common Errors in the phonological system and the FT AD in Relation to the Percentage of Hits on FTAD

\begin{tabular}{|c|c|c|c|c|c|c|c|}
\hline $\begin{array}{c}\text { Range of correct } \\
\text { FDTA }\end{array}$ & $\begin{array}{c}\mathrm{N}^{\mathrm{o}} \\
\text { subject }\end{array}$ & $\begin{array}{c}\text { Mean errors } \\
\text { PS }\end{array}$ & $\begin{array}{c}\text { d.p. errors } \\
\text { PS }\end{array}$ & $\begin{array}{c}\text { Mean common errors } \\
\text { (PS and FDTA) }\end{array}$ & $\begin{array}{c}\text { d.p. common } \\
\text { errors }\end{array}$ & $r^{*}$ & p- amount \\
\hline 40 a $49 \%$ & 2 & 10,5 & 3,535534 & 8,5 & 2,12132 & & \\
\hline 50 a $59 \%$ & 1 & 13 & - & 11 & - & & \\
\hline 60 а $69 \%$ & 6 & 6,66 & 1,861899 & 5 & 1,67332 & & \\
\hline 70 а $79 \%$ & 9 & 6,33 & 3,4278273 & 2,55 & 1,6158933 & $-6,647114277$ & 0,0000000656 \\
\hline 80 а $89 \%$ & 10 & 6,9 & 4,121758 & 1,9 & 2,260777 & & \\
\hline 90 а $99 \%$ & 11 & 7 & 4,266146 & 0,9 & 0,700649 & & \\
\hline $100 \%$ & 2 & 5 & 1,414214 & $\begin{array}{l}\text { No hit } \\
\text { total FTAD }\end{array}$ & - & & \\
\hline
\end{tabular}

*Spearman correlation

Legend: S.F.- PS- phonological System; d.p.- Standard deviation; FTAD - Figures Test for Auditory Discrimination

\section{Discussion}

Despite not being statistically significant difference between the sexes, in general, females performed better in FTAD (11) than males.

This result agrees with a study that evaluated (6) children with communication disorder. In this study, de not found statistical difference in performance between the sexes, except for individuals located in the age between 6 years and 6:5 years and years between 7:6 and 7:11 years, both with better performance of females.

Also (16), in a research with children PD, the results indicated that females exhibit a better performance in FTAD (11).

According to Table 1, there is a significant positive correlation between the age of the subjects and percentage of correct FTAD. In a study (6), also noted a change for the better, following the chronological age, performance children in auditory discrimination tasks. Other authors (16-17) also found that this ability improves with advancing chronological age.

Studies (18-20) which sought to evaluate the discrimination of sounds in young children has been shown that these children require larger acoustic differences and more time to discriminate consonant sounds than the older children or adults.

One factor that may have influenced the outcome of the statistical comparison between the average score on the FTAD and the degree of the disorder is non-homogeneous distribution of the sample in different degrees of severity of the PD. Therefore, it is important to repeat this analysis in more homogeneous sample.

In the study of children with PD (10), the results show a better performance in the ability of auditory discrimination in subjects who had PD medium grade, than those who had medium-moderate or moderately severe. It was concluded that a relationship between the severity of the PD and auditory discrimination, which is better in less severe deviation.

The classification results of the study subjects in relation to the percentage of correct answers, suggest a higher frequency of disability discrimination hearing in children with PD. This is because the reference values of the test were obtained from the data of children with communication disorder in which all managed to out performance $80 \%$ of corrects (15). However, 43.88\% of children in this sample failed to achieve satisfactory performance. And of these, $21.93 \%$ had a performance

much lower than expected $(<60 \%)$.

One hypothesis for the cause of the PD would be that the disorder in the production of sound is the result of a difficulty in discrimination (10). It is believed that the results may suggest a causal relationship between disability discrimination and auditory PD, however, does not apply to all children.

As can be seen in Table 2, the greater the severity of the PD greater the number of phonemes in the phonological system changed. Only the severe group makes this number of errors does not increase linearly, although it should consider the fact that this 
group has only one representative, as the result of other groups stems from an average.

Therefore, one may say that, in general, more severe PD greater the number of phonemes for which the child has hearing disability discrimination, which may be a causative or aggravating factor of the PD.

The results in Table 3 support the previous discussion of the topic, that the inability of auditory discrimination would be a causal or aggravating factor for the PD.

The hypothesis that prompted this research is that the change in auditory discrimination of speech sounds could lead to change in the production of these sounds. The goal was to determine whether a sound that has change in the phonological system is badly discriminate when compared to other sound. It is believed that the results prove this hypothesis in part, as they relate to the most common errors in the lowest percentage of correct FTAD or greater severity of the PD.

\section{Conclusion}

After this research accomplish and analysis, datas it can be concluded regarding the ability of auditory discrimination in children with PD:

. there was no difference in performance in FTAD between the sexes. For further research, suggest it the use of a greater number of subjects and an evaluation in range of age to see if there are moments of difference between the sexes according to children's development;

. the best performance in FTAD is correlated with advancing chronological age;

. the more severe the $\mathrm{PD}$, the greater the number of phonemes for which the child has hearing disability discrimination;

. the inability of auditory discrimination may be a causal or aggravating factor of the PD, but does not apply to all cases. 


\section{Appendix}

Protocol figures test for auditory discrimination (FTAD).

Evaluation of auditory discrimination protocol test response.

Name: Date of birth: $\quad$ Current age: Date of application:

\begin{tabular}{|c|c|c|c|c|c|c|c|c|c|}
\hline & Peers - test & A & B & $\mathrm{C}$ & & Peers - retest & $\mathrm{A}$ & $\mathrm{B}$ & $\mathrm{C}$ \\
\hline 01. & Pot-pot & & & & 01. & Pot-boat & & & \\
\hline 02. & boat-goat & & & & 02. & boat-boat & & & \\
\hline 03. & Seat-belt & & & & 03. & Belt-five & & & \\
\hline 04. & Data-cat & & & & 04. & Cat-cat & & & \\
\hline 05. & glue-collar & & & & 05. & glue-glue & & & \\
\hline 06. & Knife-cow & & & & 06. & Cow-Cow & & & \\
\hline 07. & Talk-talk & & & & 07. & Talk-room & & & \\
\hline 08. & Leaf-leaf & & & & 08. & Leaf-stopper & & & \\
\hline 09. & Cell-candles & & & & 09. & Cell-cell & & & \\
\hline 10. & Five-zinc & & & & 10. & Zinc-Zinc & & & \\
\hline 11. & Serum-serum & & & & 11. & Cry-cry & & & \\
\hline 12. & Zipper-Jeep & & & & 12. & Zipper-zipper & & & \\
\hline 13. & Chin-cheese & & & & 13. & Cheese-cheese & & & \\
\hline 14. & Double-bed & & & & 14. & Reed-bed & & & \\
\hline 15. & moon-moon & & & & 15. & naked-moon & & & \\
\hline 16. & Sailing-old & & & & 16. & Candle-candle & & & \\
\hline 17. & Mail-Mara & & & & 17. & Mail-mail & & & \\
\hline 18. & Glove-grape & & & & 18. & Glove-Glove & & & \\
\hline 19. & Street-moon & & & & 19. & Street-street & & & \\
\hline 20. & Car-car & & & & 20. & Expensive car & & & \\
\hline 21. & Tune-toast & & & & 21. & toast - toast & & & \\
\hline 22. & Caio-car & & & & 22. & Car-car & & & \\
\hline 23. & even -father & & & & 23. & even - even & & & \\
\hline 24. & Shovel- even & & & & 24. & Bang-bang & & & \\
\hline 25. & Tile-tile & & & & 25. & Tile-web & & & \\
\hline
\end{tabular}

Result: \% correct 


\section{References}

1. Ribas A. A influência do meio social sobre o desenvolvimento da percepção auditiva em crianças. J Bras Fonoaudiol. Curitiba. 2001;2(8):224-8.

2. Philips DP. Central auditory processing: a view from auditory neuroscience. Am J Otology. 1995;16:338-52.

3. Meyer TA, Bilger RC. Effect of set size and method on speech reception threshold in noise. Ear and Hearing. 1997; 18:202-9.

4. Tristão RM, Feitosa MAG. Percepção da fala em bebês no primeiro ano de vida. Estudos de Psicologia. Natal. 2003; 8

5. Kuhl PK. Early language acquisition: Cracking the speech code. Nature Reviews. Neuroscience. 2004;5:831-43.

6. Rodrigues EJB. Discriminação auditiva: normas para avaliação de crianças de 5 a 9 anos. $1^{\circ}$ ed. São Paulo: Ed. Cortez; 1981.

7. Wertzner HF, Amaro L, Galea DES. Phonological performance measured by speech severity indices compared with correlated factors. São Paulo. Med J. 2007;125(6): 309-14.

8. Kraus N, Mcgee T, Carrel TD, Sharma A. Neurophysiologic bases of speech discrimination. Ear Hear. 1995;16(1):19-37.

9. Boets B, Wouters J, van Wieringen A, et al. Modelling relations between sensory processing, speech perception, orthographic and phonological ability, and literacy achievement. Brain and Language. 2008;106(1):29-40.

10. Santos B, Bagetti T, Kist FRZ, Mota HB, Keske-Soares M. Relação entre o grau de severidade do desvio fonológico e a discriminação auditiva. In: V Congresso Internacional, XI Congresso Brasileiro e I Encontro Cearense de Fonoaudiologia, Fortaleza, 2003. Resumos... Fortaleza: [sn]; 2003.

11. Mota HB, Keske-Soares M, Vieira MG. Teste de figuras para discriminação auditiva adaptado do the Boston University speech sound discrimination picture test. Santa Maria, RS, 2000. Teste utilizado no CELF/SAF da UFSM, não publicado.
12. Yavas MS, Hernandorena CLM, Lamprecht RR. Avaliação fonológica da criança - reeducação e terapia. $2^{\circ}$ ed. Porto Alegre: Ed. Artes Médicas; 1992.

13. Kamhi AG. Treatment decisions for children with speech-sound disorders. Language Speech and Hear Services in Schools. 2006;37(4): 271-9.

14. Grunwell P. Os desvios fonológicos evolutivos numa perspectiva lingüística. In: Yavas MS. Desvios fonológicos em crianças: teoria, pesquisa e tratamento. Porto Alegre: Ed. Mercado Aberto; 1990. p. 51-82.

15. Keske-Soares M, Ferla A, Molz AL, Radunz C, Santos CCS, Brizuela CP, Fonseca CF. O Estudo da discriminação auditiva em pré-escolares: resultados parciais. In: IX Semana Acadêmica da Fonoaudiologia, Santa Maria, 2000. Resumos... Santa Maria: [sn]. 2000.

16. Santos B, Silva AS, Mota HB, Keske-Soares M. Habilidade de discriminação auditiva em relação às variáveis sexo e idade. In: XII Congresso Brasileiro de Fonoaudiologia, II Encontro Sul Brasileiro de Fonoaudiologia, Foz do Iguaçu, 2004. Resumos... Foz do Iguaçu: [sn], 2004.

17. Hazan V, Barrett S. The development of phonemic categorization in children aged 6-12. Journal of phonetics. 2000;28(4):377-96.

18. Elliot LL, Hammer MA. Fine-Grained Auditory Discrimination: Factor Structures. J Speech Hear Res. 1993; 36(2):396-409.

19. Cacace AT, McFarland DJ, Ouimet JR, et al. Temporal processing deficits in remediation-resistant reading-impaired children. Audiology and Neuro-otology. 2000;5(2):83-97.

20. Elfenbein JL, Small AM, Davis JM. Developmental patterns of duration discrimination. J Speech Hear Res. 1993;36(4):842-9. 